\title{
DIAGNOSIS OF ALPHA-1-ANTITRYPSIN DEFICIENCY BY DNA ANALYSIS OF CHILDREN WITH LIVER DISEASE*
}

\author{
Adriana Maria Alves De TOMMASO ${ }^{1}$, Cláudio Lúcio ROSSI ${ }^{2}$, \\ Cecília Amélia Fazzio ESCANHOELA ${ }^{3}$, Heliane Guerra SERRA ${ }^{4}$, \\ Carmen Sílvia BERTUZZO ${ }^{5}$ and Gabriel HESSEL ${ }^{6}$
}

\begin{abstract}
Background - Alpha-1-antitrypsin deficiency is a genetic disorder which is transmitted in a co-dominant, autosomal form. Alpha-1-antitrypsin deficiency affects mainly the lungs and the liver leading, in the latter case, to neonatal cholestasis, chronic hepatitis or cirrhosis. A precise diagnosis of Alpha-1-antitrypsin deficiency may be obtained by biochemical or molecular analysis. Objective - The purpose of this study was to use DNA analysis to examine the presence of an alpha-1-antitrypsin deficiency in 12 children suspected of having this deficiency and who showed laboratory and clinical characteristics of the disease. Patients and Methods - Twelve patients, aged 3 months to 19 years, who had serum alpha-1-antitrypsin levels lower than normal and/or had hepatic disease of undefined etiology were studied. The mutant alleles $S$ and $Z$ of the alpha-1-antitrypsin gene were investigated in the 12 children. Alpha-1-antitrypsin gene organization was analyzed by amplification of genoma through the polymerase chain reaction and digestion with the restriction enzymes Xmnl (S allele) and Taq 1 (Z allele). Results - Seven of the 12 patients had chronic liver disease of undefined etiology and the other five patients had low serum levels of alpha-1-antitrypsin as well as a diagnosis of neonatal cholestasis and/or chronic liver disease of undefined etiology. Five of the 12 patients were homozygous for the Z allele (ZZ) and two had the $S$ allele with another allele $\left({ }^{*} S\right)$ different from Z. Conclusion - These results show that alpha-1-antitrypsin deficiency is relatively frequent in children with chronic hepatic disease of undefined etiology and/or low alpha-1-antitrypsin levels (41.6\%). A correct diagnosis is important for effective clinical follow-up and for genetic counseling.
\end{abstract}

HEADINGS - Alpha-1-antitrypsin deficiency. Molecular diagnosis. Liver biopsy.

\footnotetext{
* Study conducted by the Departments of Pediatrics, Medical Genetics, Anatomical Pathology and Clinical Pathology of the Faculty of Medical Sciences (FCM), State University of Campinas - UNICAMP, Campinas, SP, Brazil.

Postgraduate student. Department of Pediatrics, FCM/UNICAMP.

Assistant Professor. Department of Clinical Pathology, FCM/UNICAMP.

Assistant Professor. Department of Anatomical Pathology, FCM/UNICAMP.

PhD in Genetics (Institute of Biology), UNICAMP.

Assistant Professor. Department of Medical Genetics, FCM/UNICAMP.

Assistant Professor. Department of Pediatrics, FCM/UNICAMP.

Address for correspondence: Dr. Adriana Maria Alves De Tommaso - Departamento de Pediatria - FCM/UNICAMP - Caixa Postal 6111 - $13083-970$ - Campinas, SP, Brazil. e-mail: amdetommaso@hotmail.com.
} 


\section{INTRODUCTION}

Alpha-1-antitrypsin (A1AT) is a $52 \mathrm{kDa}$ glycoprotein produced mainly by hepatocytes which release $2 \mathrm{~g}$ of this protein, per day, into the blood stream ${ }^{(36)}$. The main function of A1AT is to inhibit the action of neutrophilic elastase, a serine protease that hydrolyzes elastin fibers in the lungs ${ }^{(38)}$. Mutations in the gene encoding for A1AT produce a protein with no inhibitory capacity and may lead to the accumulation of A1AT in inclusion corpuscles in hepatocytes, thereby a reducing the normal serum levels of this protein ${ }^{(4)}$. This deficiency is reflected as lung emphysema, chronic bronchitis or bronchiectasis ${ }^{(9)}$. The accumulation of mutant A1AT in hepatocytes may also lead to neonatal cholestasis, chronic hepatopathy or cirrhosis ${ }^{(33,34)}$.

The A1AT gene is highly polymorphic, co-dominant and is located on the longer arm of chromosome 14 (14q 31-32.3) ${ }^{(20,29)}$. Seventy-five alleles (designated A-Z acording to their isoeletric points) have been described for this gene based on isoelectric focusing of serum between pH 4 (anode) and pH 5 (cathode) in polyacrylamide gels. The common variants migrate to the center of the gel and therefore belong to the $\mathrm{M}$ ("middle") family. A deficient variant, originally described by LAURELL and ERIKSSON in $1963^{(21)}$, migrates towards the cathode and is denominated Z. Another variant, which moves slowly in the gel, is denominated $\mathrm{S}^{(5)}$. This polymorphic "locus" is generally know as the $\mathrm{Pi}$ (protease inhibitor) system. Most of the variants produce A1AT of normal quantity and quality ${ }^{(7,8,25)}$. However, some alleles such as variants $\mathrm{S}$ and $\mathrm{Z}$ are associated with a deficient condition that attains polymorphic frequencies as Caucasian populations and cases of a null allele in which protein production is totally absent have been reported ${ }^{(10)}$.

The $\mathrm{S}$ allele results from the substitution of adenine by thiamin in exon III of the gene, which leads to glutamic acid at position 264 being exchanged for valine and the consequent formation of an unstable protein structure $^{(10,11,19)}$. The $\mathrm{Z}$ allele results from the substitution of guanine at position 342 by adenine in exon $\mathrm{V}$ of the gene and leads to the formation of a protein that collects on the inner rough surface of the hepatocyte endoplasmic reticulum ${ }^{(6)}$. The diagnosis of a deficient condition is usually made after quantification of the serum levels of the protein together with electrophoretic profile after isoelectric focusing ${ }^{(23,37)}$. A more precise diagnosis requires gene analysis using DNA based techniques ${ }^{(12,14,26)}$.

The objective of this study was to identify $\mathrm{S}$ and $\mathrm{Z}$ allele carriers in patients suspected of having this deficiency and who showed laboratory and clinical characteristics of this disease.

\section{PATIENTS AND METHODS}

\section{Patients}

During the period from February, 1988 to August, 1997, a great number of patients were referred to the Pediatric Gastroenterological
Service, State University of Campinas, Campinas, SP, Brazil, in order to investigate hepatic diseases. From this number only 12 patients did not show any definite diagnosis (negative results to viral hepatitis, autoimmune hepatitis and Wilson's disease). Those patients were undergone to a molecular analysis of A1AT.

\section{Methods}

\section{1 - Study Protocol}

A protocol was filled in with data on the levels of the following parameters: 1). serum level of A1AT determined by radial immunodiffusion (normal values of 1.9-3.5 g/L) or nephelometry (Array ${ }^{\circledR} 360$ System, Beckman Instruments, Inc., USA - normal level of 0.83-1.99 g/L); 2). alanine aminotransferase (ALT, normal serum levels up to $40 \mathrm{U} / \mathrm{L}$ ); 3). alkaline phosphate (AP, normal serum levels up to $645 \mathrm{U} / \mathrm{L}$ ), and 4). gammaglutamyl transpeptidase $(\gamma \mathrm{GT}$, normal levels of up to $50 \mathrm{U} / \mathrm{L}$ for males and $32 \mathrm{U} / \mathrm{L}$ for females).

\section{2 - Liver Biopsy}

Percutaneous liver biopsies were obtained as described by MOWAT $^{(24)}$ using local anesthesia in patients fasted for at least $4 \mathrm{~h}$, with venoclysis and normal prothrombin activity. The fragment obtained was immediately placed in $10 \%$ formalin and then processed and stained with hematoxylin-eosin, Masson's trichromic, Prussian blue and silver impregnation of the reticulum fibers. Special staining was obtained using PAS (periodic acid-Schiff) followed by treatment with diastase. The persistence of eosinophil-appearing cytoplasmic granules even after use of diastase was considered positive for A1AT deficiency.

\section{3 - Molecular analysis}

In order to investigate the mutant alleles $\mathrm{S}$ and $\mathrm{Z}$ of the A1AT, it was done a DNA extraction of peripheral blood leukocytes as used in the method described by WOODHEAD et al. ${ }^{(39)}$.

DNA analysis was done using a modified method of amplification involving the polymerase chain reaction (PCR) which creates restriction sites for the enzymes XmnI (S allele) and Taq I ( $\mathrm{Z}$ allele $)^{(2,}$ ${ }^{30)}$. The primers used for the $\mathrm{S}$ allele were p7553 (5'-CGTTTAGGCATGAATAACTTCCAGC-3'), p7702 (5'-GATGATATCGTGGGTGAGAACATTT-3') and p7702 (5'-GATGATATCGTGGGTGAGAACATTT-3'). The primers for Z allele were p9966 (5'ATAAGGCTGTGCTGACCATCGTC-3') and p10063 (5'TATTCCGACACGACTGGTAGCAG-3'). 


\section{RESULTS}

Five of the 12 children studied were $Z$ homozygotes $(\mathrm{ZZ})$ whereas two of the children had the $S$ allele together with another allele which was not $Z(* S)$. Table 1 shows the patient's age at the time of blood collection and the indication used for deciding for subsequent analysis. Three of the patients presented neonatal cholestasis as an initial manifestation of chronic hepatopathy.
Table 2 shows the serum levels of ALT, AP, $\gamma \mathrm{GT}$, A1 AT as well as the results of the molecular study and liver biopsy.

The five patients with the ZZ genotype had reduced serum A1AT levels and the liver biopsy showed cirrhosis (one), neonatal hepatitis (two), a paucity of interlobular bile ducts (one) and chronic hepatitis (one). In this last case (FSP), eosinophil-appearing cytoplasmic granules were seen in periportal hepatocytes following staining with $\mathrm{HE}$ and posteriorly confirmed by PAS positivity and diastase

Table 1 - Ages of the patients at the time of DNA analysis and the indications used in their selection

\begin{tabular}{lcl}
\hline Patient & AGE & Indication for DNA analysis \\
\hline MFS & $9 \mathrm{y}$ & Chronic hepatic disease of no defined etiology; A1AT $\downarrow$ \\
EKBA & $3 \mathrm{~m}$ & Neonatal cholestase; A1AT $\downarrow$ \\
RHBP & $5 \mathrm{y}$ & Neonatal cholestase; chronic hepatic disease of no defined etiology; A1AT $\downarrow$ \\
JCI & $1 \mathrm{y}$ & Neonatal cholestase; Chronic hepatic disease of no defined etiology; A1AT $\downarrow$ \\
FSP & $3 \mathrm{y}$ & Chronic hepatic disease of no defined etiology; A1AT $\downarrow$ \\
DO & $19 \mathrm{y}$ & Chronic hepatic disease of no defined etiology \\
FSB & $13 \mathrm{y}$ & Neonatal cholestase; Chronic hepatic disease of no defined etiology \\
TA & $11 \mathrm{y}$ & Chronic hepatic disease of no defined etiology \\
CABC & $8 \mathrm{y}$ & Chronic hepatic disease of no defined etiology \\
DPC & $11 \mathrm{y}$ & Chronic hepatic disease of no defined etiology \\
YCPM & $8 \mathrm{~m}$ & Chronic hepatic disease of no defined etiology \\
JRA & $6 \mathrm{y}$ & Chronic hepatic disease of no defined etiology \\
\hline
\end{tabular}

Table 2 - Hepatic enzyme activities (IU/L), serum A1AT levels (g/L), liver biopsy results and individual's genotype

\begin{tabular}{lcccccc}
\hline Patient & ALT(IU/L) & AP(IU/L) & $\mathbf{G T}(\mathbf{I U} / \mathbf{L})$ & A1AT(g/L) & Biopsy & Genotype \\
\hline MFS & 159 & 886 & 66 & Undetect. & Cirrhosis \# & ZZ \\
EKBA & 50 & 45 & 974 & 0,86 & Neonatal hepatitis \# & ZZ \\
RHBP & 696 & 1212 & 639 & 1,20 & Intrahepatic biliary hipoplasia \# & ZZ \\
JCI & 394 & 4285 & 817 & 0,46 & Neonatal hepatitis \#\# & ZZ \\
FSP & 139 & 2503 & 887 & $0,40 * *$ & Chronic hepatitis with portal fibrosis \# & ZZ \\
DO & 44 & 1345 & 174 & 4,80 & Chronic hepatitis and cirrhosis & $*$ S \\
FSB & 146 & 1944 & 325 & 2,00 & Portal fibrosis and ductupenia & *S \\
TA & 29 & 429 & 24 & 3,10 & Portal fibrosis & NEG. SZ \\
CABC & 340 & - & 84 & 2,40 & Chronic hepatobiliary disease & NEG. SZ \\
DPC & 26 & 632 & 27 & 3,40 & Hepatocellular degeneration & NEG. SZ \\
YCPM & 84 & 822 & 33 & 3,60 & Chronic active hepatitis & NEG. SZ \\
JRA & 15 & 13 & 45 & 0,85 & & NEG. SZ \\
\hline
\end{tabular}

\# PAS positive globules/diastase resistant

\#\# PAS positive globules/diastase resistant in second biopsy

** A1AT levels determined by nephelometry. The other levels were determined by radial immunodiffusion. 
resistance (Figure 1). The two patients with neonatal cholestasis (EKBA and RHBP) underwent a liver biopsy when they were 10 weeks and 13 weeks old, respectively, and showed eosinophilic PASpositive, diastase-resistent globules.

Figures 2 and 3 show the results of the amplification and digestion of the $\mathrm{S}$ and $\mathrm{Z}$ alleles, respectively.

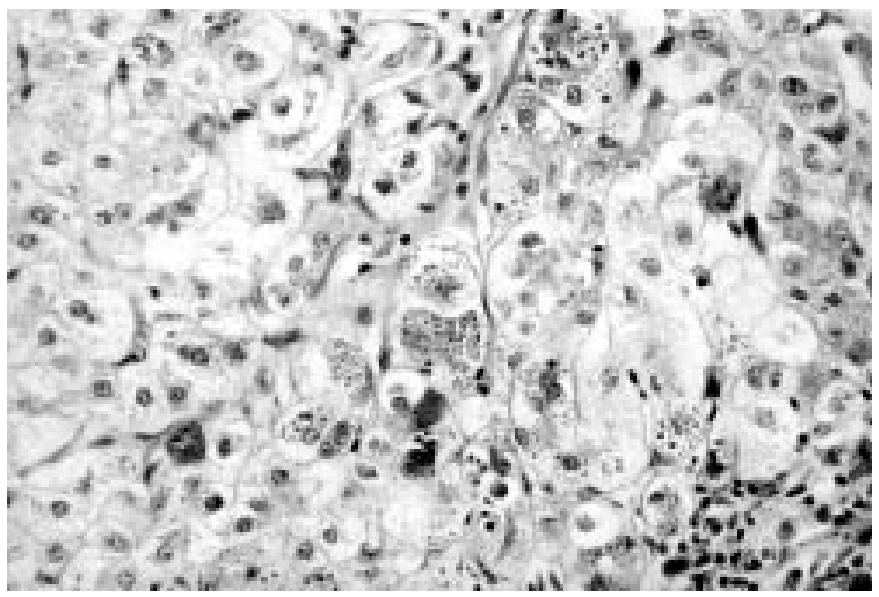

FIGURE 1 - PAS-positive, diastase-resistant globules in periportal hepatocytes. (PAS 400X)

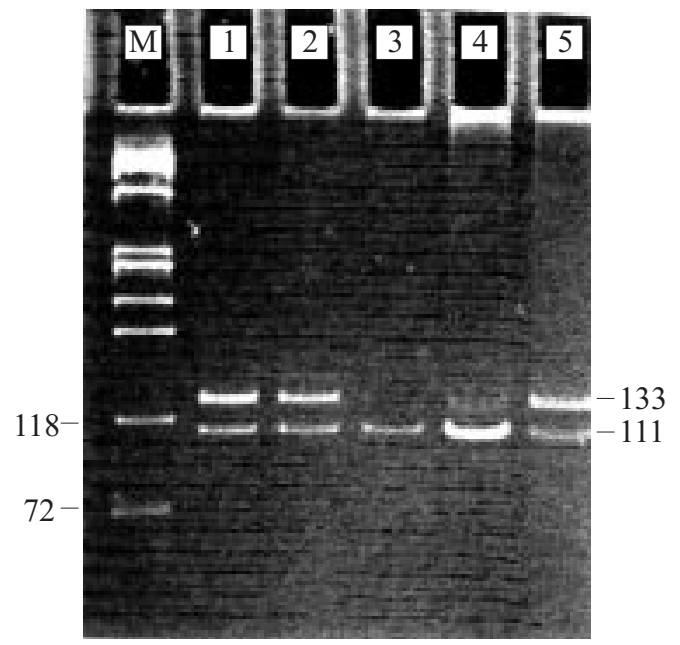

FIGURE 2 - Ethidium bromide stained polyacrylamide gel showing the profile of normal and mutant A1AT digested with the the restriction enzyme (Xmnl). Lanes 1, 2,4 and 5$\mathrm{S}$ heterozygotes, lane 3-normal homozygote, M-marker (X 174/Hind III)

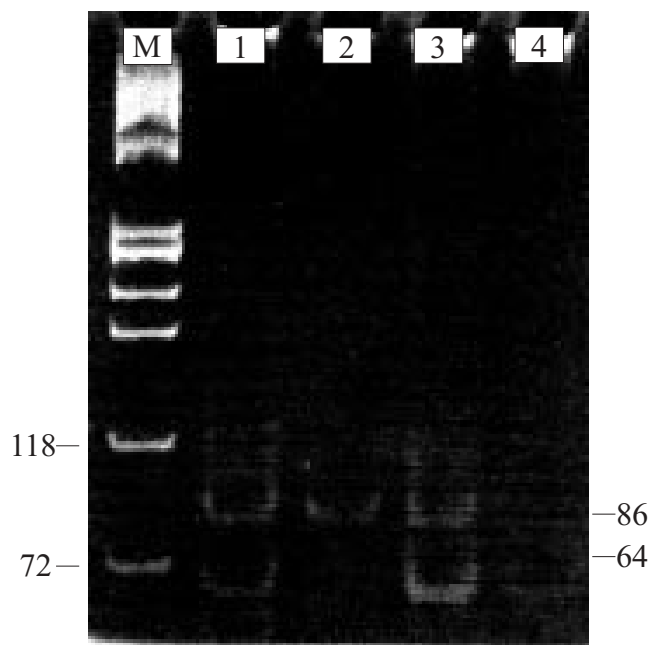

FIGURE 3 - Ethidium bromide stained polyacrylamide gel showing the profile of normal and mutant A1AT digested with the restriction enzyme (Taq I). Lanes 1 and $3-\mathrm{Z}$ heterozygotes, lane 2- Z homozygote, lane 4- normal homozygote, M-marker (X 174/Hind III)

\section{DISCUSSION}

Alpha-1-antitrypsin deficiency is one of the most common genetic disorders that leads to hepatic disease in children and it is the most common genetic disease requiring liver transplantation ${ }^{(17,28)}$. A1AT deficiency affects 1 out of 1600-2000 neonates in North America and Northern Europe ${ }^{(28,31)}$, but only $10-15 \%$ of the population with this deficiency develop hepatic diseases ${ }^{(32,33)}$. According to a study published by SVEGER in $1988^{(33)}$, during the neonatal period $11 \%$ of the patients with the PIZZ phenotype develop icteric hepatitis. In this study, three patients diagnosed with an A1AT deficiency had neonatal cholestasis and in two of these, before a definite diagnosis of the deficiency was established, the cholestasis was considered idiopathic. Five to 10 percent of the cases of idiopathic neonatal hepatitis reported in the literature are caused by an A1AT deficiency ${ }^{(3)}$.

In five patients with this deficiency studied, the serum levels of A1AT were below the normal lower limit. However, this test did not absolutely confirm the diagnosis of the disease. Since A1AT is a protein of the acute inflammatory phase, its synthesis increases in inflammatory/ infectious conditions, neoplasia, pregnancy and during therapy using estrogens and corticosteroids ${ }^{(16,22)}$. A reduction in the serum levels of A1AT occurs in the respiratory anguish syndrome of neonates, in the terminal phase of hepatic failure, in cystic fibrosis and in situations in which there is great protein loss ${ }^{(15)}$. The serum levels in SZ genotypes, which could theorically result in liver diseases, are usually normal.

When neonatal cholestasis is present, it is fundamentally necessary a differential diagnosis with extrahepatic biliary atresia. The clinical 
history allows an adequate diagnoses in $83 \%$ of the $\operatorname{cases}^{(1)}$ and it is necessary specific investigations in order to improve the accuracy of the diagnosis. Among these investigations, the liver biopsy is of major importance. The histopathological alterations seen in the liver biopsy of patients with A1AT deficiency may be the same as those observed in idiopathic neonatal hepatitis or in cases of extrahepatic biliary $\operatorname{atresia}^{(24)}$. The presence of predominantly periportal, intrahepatocystic globules that are strongly PAS positive after diastase digestion is a helpful indication of A1AT deficiency ${ }^{(13,18,27)}$. However, it is difficult to identify these globules before the $12^{\text {th }}$ week after birth ${ }^{(35)}$. In this study, patient EKBA had globules with the above characteristics in liver tissue at the age of 10 weeks. No such globules were seen in patient JCI (13 weeks old). These results suggest that the presence of globules should be investigated using special staining in hepatic fragments obtained before the age of 12 weeks, although a negative result does not eliminate the possibility of A1AT deficiency. Biochemical analysis was not used in this study since DNA analysis, which is more precise, was possible.

An A1AT deficiency is relatively frequent in children who have hepatic disease of undefined etiology. This diagnosis is subestimated, probably because imprecise diagnostic methods are used. Molecular analysis provides a more precise diagnosis and may also be useful for the genetic counseling of patients with hepatic disease of unknown etiology.

De Tommaso AMA, Rossi CL, Escanhoela CAF, Serra HG, Bertuzzo CS, Hessel G. Diagnóstico da deficiência de alfa-1-antitripsina por estudo molecular em crianças com doença hepática. Arq Gastroenterol 2001;38(1):63-68.

RESUMO - Racional - A deficiência de alfa-1-antitripsina é uma doença genética transmitida de forma autossômica co-dominante. As manifestações clínicas principais incluem acometimento pulmonar e hepático. Este último, apresenta-se como colestase neonatal, hepatite crônica ou cirrose. O diagnóstico definitivo é realizado pela análise bioquímica da alfa-1-antitripsina ou pela análise molecular. Objetivo - Investigar, em um grupo de 12 crianças com suspeita de deficiência de alfa-1-antitripsina, a presença efetiva da deficiência através da análise de DNA, para um diagnóstico definitivo, bem como a associação entre os deficientes de alfa-1-antitripsina com as características clínicas e laboratoriais encontradas. Casuística e Métodos - Foram investigados os alelos mutantes $S$ e Z do gene da alfa-1-antitripsina em 12 pacientes com idade variando de 3 meses a 19 anos, encaminhadas pelo ambulatório de Gastroenterologia Pediátrica da Universidade Estadual de Campinas, SP, por apresentarem dosagem sérica de alfa-1-antitripsina inferior ao normal elou doença hepática sem etiologia definida. A análise de DNA foi realizada utilizando-se o método modificado de amplificação gênica pela reação em cadeia de polimerase que cria sítios de restrição para as enzimas Xmnl (alelo S) e Taq l (alelo Z). Resultados - Dos 12 pacientes encaminhados, 7 apresentavam doença hepática crônica sem etiologia definida e os outros 5 traziam dosagens séricas baixas de alfa-1-antitripsina acompanhadas do diagnóstico de colestase neonatal elou doença hepática crônica de etiologia desconhecida. Nesse grupo de 12 pacientes, foram observados cinco pacientes homozigotos $Z$ (ZZ) e dois traziam o alelo $S$ acompanhado de um outro alelo, diferente do $Z$ (*S). Conclusão - Esses resultados mostram que a deficiência de A1AT é uma etiologia relativamente freqüente em crianças que apresentam doença hepática crônica sem etiologia definida elou dosagem sérica baixa de A1AT (41,6\%). A importância de um diagnóstico de certeza para a deficiência é justificada não apenas para o seguimento clínico do paciente mas também, em termos de aconselhamento genético.

DESCRITORES - Deficiência de alfa-1-antitripsina. Diagnóstico molecular. Biopsia hepática.

\section{REFERENCES}

1. Alagille D. Cholestasis in the first three months of life. Prog Liver Dis 1979;6:471-85

2. Andresen BS, Knudsen I, Jensen PKA, Gregersen N. Two novel nonradioactive polymerase chain reaction-based assays of dried blood spots, genomic DNA, or whole cells for fast, reliable detection of $\mathrm{Z}$ and $\mathrm{S}$ mutations in the Alpha-1antitrypsin gene. Clin Chem 1992;38:2100-7.

3. Balistreri WF, Schubert WK. Liver disease in infancy and childhood. In: Schiff L, Schiff ER, editors. Diseases of the liver. 7.ed. Philadelphia: Lippincott; 1993. p.1099-1203.

4. Billingsley GD, Cox DW. Functional assessment of genetic variants of alpha 1antitrypsin. Hum Genet 1982;61:118-22.

5. Brantly M, Nukiwa T, Crystal RG. Molecular basis of alpha-1-antitrypsin deficiency. Am J Med 1988;84:13-31.

6. Carlson JA, Rogers RB, Sifers R. Acumulation of PiZ alpha 1-antitrypsin causes liver damage in transgenic mice. J Clin Invest 1989;83:1183-90.
7. Carrel RW. Alpha 1-antitrypsin: molecular pathology, leukocytes and tissue damage. J Clin Invest 1986;78:1427-31.

8. Cox DW, Woo SL, Mansfield T. DNA restriction fragments associated with alpha 1-antitrypsin indicate a single origin for deficiency allele PI Z. Nature 1985;316:79-81.

9. Crystal RG, Brantly ML, Hubbard RC, Curiel DT, States DJ, Holmes MD. The alpha 1-antitrypsin gene and its mutations. Clinical consequences and strategies for therapy. Chest 1989;95:196-208.

10. Crystal RG, Ferrans VJ, Basset F. Biologic basis of pulmonary fibrosis. In: Crystal RG, West JB, Barnes PJ, Cherniack S, editors. The lung: scientific foundations. New York; Raven Press: 1991. p.2031-46.

11. Curiel D, Brantly M, Curiel E, Crystal RG. Alpha-1-antitrypsin deficiency caused by the alpha-1-antitrypsin Nullmattawa gene. An insertion mutation rendering the alpha-1-antitrypsin gene incapable of producing alpha-1-antitrypsin. J Clin Invest 1989;83:1144-52.

12. Dermer SJ, Johnson EM. Rapid DNA analysis of alpha 1-antitrypsin deficiency: application of an improved method for amplifying mutated gene sequence. Lab Invest 1988;59:403-8. 
De Tommaso AMA, Rossi CL, Escanhoela CAF, Serra HG, Bertuzzo CS, Hessel G. Diagnosis of alpha-1-antitrypsin deficiency by DNA analysis of children with liver disease

13. Deutsch J, Becker H, Auböck L. Histopathological features of liver disease in alpha 1-antitrypsin deficiency. Acta Paediatr 1994;393 Suppl:8-12.

14. Dubel JR, Finwick R, Hejtmancik JF. Denaturing gradient gel electrophoresis of the alpha 1-antitrypsin gene: application to prenatal diagnosis. Am J Med Genet 1991;41:39-43.

15. Evans HE, Levi M, Mandl I. Serum enzyme inhibitor concentrations in the respiratory distress syndrome. Am Rev Resp Dis 1970;101:359-63.

16. Fagerhol MK, Cox DW. The PI polimorphism: genetic, biochemical and clinical aspects of human alpha-1-antitrypsin. In: Harris H, Hirchorn, K, editors. Human genetic. New York: Plenum; 1981. p. 1-62.

17. Gartner JC, Zitelli BJ, Malatak JJ, Shaw BW, Iwatsuki S, Starzl TE. Orthotopic liver transplantation in children: two-year experience with 47 patients. Pediatrics 1984;74:140-5.

18. Ishak KG. Hepatic morphology in inherited metabolic diseases. Sem Liver Dis 1986;6:246-58.

19. Jeppsson JO, Laurell CB, Fagerhol MK. Properties of isolated alpha-1antitrypsin of Pi types M, S and Z. Eur J Biochem 1978;83:143-53.

20. Lai EC, Kao FT, Law ML, Woo SL. Assignment of the alpha 1-antitrypsin gene and a sequence-related gene to human chromossome 14 by molecular hybridization. Am J Hum Genet 1983;35:385-92.

21. Laurell CB, Eriksson S. The electrophoretic alpha-1-globulin pattern of serum in alpha-1-antitrypsin deficiency. Scand J Clin Lab Invest 1963;15:132-40.

22. Laurell CB, Kullander S, Thorell J. Effect of administration of a combined strogen-progestin contraceptive on the level of individual plasma proteins. Scand J Clin Lab Invest 1968;21:337-43.

23. Massi G, Chiarelli C. Alpha 1-antitrypsin: molecular and the Pi system. Acta Paediatr 1994;393 Suppl:1-4.

24. Mowat AP. Avaliação laboratorial das afecções hepatobiliares. In: Mowat AP Doenças hepáticas em pediatria. 2.ed. Rio de Janeiro: Revinter; 1991. p.41030 .

25. Nukiwa T, Brantly M, Ogushi F, Crystal RG. Characterization of the M1(ala 213) type of alpha-1-antitrypsin, a newly recognized common "normal" alpha-1antitrypsin haplotype. Biochemistry 1987;26:5259-67.

26. Okayama H, Curiel DT, Brantly ML, Holmes MD, Crystal RG. Rapid nonradioactive detection of mutations in the human genome by allele-specific amplification. J Lab Clin Med 1989;114:105-13.
27. Perlmutter DH. The cellular basis for liver injury in alpha-1-antitrypsin deficiency. Hepatology 1991;13:172-85.

28. Perlmutter DH. Clinical manifestations of alpha 1-antitrypsin deficiency. Gastroenterol Clin North Am 1995;24:27-43.

29. Schroeder WT, Miller MF, Woo SL, Saunders GF. Chromosomal localization of the human alpha 1-antitrypsin gene (PI) to 14q31-32. Am J Hum Genet 1985;37:868-72.

30. Serra HG. Identificação molecular dos alelos $\mathrm{S}$ e $\mathrm{Z}$ do gene da alfa-1-antitripsina em um grupo de pacientes portadores de doença pulmonar crônica [tese de doutorado]. Campinas, SP: Instituto de Biologia da Universidade Estadual de Campinas; 1998.

31. Silverman EK, Miletich JP, Pierce JA, Sherman LA, Endicott SK, Broze GJ, Campbell EJ. Alpha-1-antitrypsin deficiency. High prevalence in the St. Louis area determined by direct population screening. Am Rev Respir Dis 1989;140:961-6.

32. Sveger T. Liver disease in alpha 1-antitrypsin deficiency detected by screening of 200,000 infants. N Engl J Med 1976;294:1316-21.

33. Sveger T. The natural history of liver disease in alpha 1-antitrypsin deficient children. Acta Paediatr Scand 1988;77:847-51.

34. Sveger T, Ericksson S. The liver in adolescents with alpha 1-antitrypsin deficiency. Hepatology 1995;22:514-7.

35. Talbot IC, Mowat AP. Liver disease in infancy. Histological features and relationship to alpha 1-antitrypsin phenotype. J Clin Pathol 1975;28:559-63.

36. Travis J, Salvesen GS. Human plasma proteinase inhibitors. Annu Rev Biochem 1983;52:655-709.

37. Van Steenbergen W. Alpha 1-antitrypsin deficiency: an overview. Acta Clin Belg 1993;48(3):171-89.

38. Wewers MD, Casolaro MA, Sellers SE, Swayze SC, McPhaul KM, Wittes JT, Crystal RG. Replacement therapy deficiency associated with emphysema. N Engl J Med 1987;316:1055-62.

39. Woodhead JL, Fallon R, Figuered H, Longdale J, Malcom ADB. Alternative methodology of gene diagnosis. In: Davies KE, editor. Human genetic diseases - a pratical approach. Oxford: IRL Press; 1986. p.51-64.

Recebido em 3/11/1999. Aprovado em 6/11/2000 